\title{
Consequences of the COVID-19 Pandemic on Veterinary Anatomy Education in India
}

\author{
Consecuencias de la Pandemia de COVID-19 en la Educación en Anatomía Veterinaria en India
}

\author{
Om Prakash Choudhary
}

CHOUDHARY, O. P. Consequences of the COVID-19 pandemic on veterinary anatomy education in India. Int. J. Morphol., 39(2):623624, 2021.

SUMMARY: As the world is struggling to cope with SARS-CoV-2, the aetiological agent of COVID-19, which has led to a global pandemic defying the geographical borders and putting the lives of billions at risk (Priyanka et al., 2020), the most critical question that remains to be elucidated by the faculty of education is whether the virtual mode of teaching will continue or we will be back to the pre-COVID scenario of teaching and learning. Being an assistant professor teaching veterinary anatomy to the students enrolled in the first-year Bachelor of Veterinary Sciences and Animal Husbandry (B.V.Sc. \& A.H.), I felt it essential to comment on the impact of COVID-19 pandemic on anatomical education (Franchi, 2020) in India. The present situation of virtual education may impact the future of current veterinary students as practically they can't be sound just depending on theories.

KEY WORDS: Veterinary anatomy education; SARS-CoV-2.

Till date, a total of 62,66,2181 cases have been reported globally to be positive for SARS-CoV-2 with a case fatality rate of approximately 2.33 percent (Worldometer, 2020); while in India, there have been 94,62,809 confirmed cases with a case fatality rate of 1.45 percent as on 1 st December 2020. In India, a country-wide lockdown was imposed on the 23rd of March 2020. Since then, most veterinary colleges and universities had suspended face to face teaching, forcing teachers and students to move to online distance learning for an indefinite period as per directives of the Government of India. We have completed almost eight months of the virtual mode of teaching, learning and assessment, and this is the right time to express the thoughts towards this "zig-zag" virtual system of teaching and learning methodology.

Few veterinary institutes started with online teaching using platforms such as Zoom and Google Meet. Education is a process and stagnation is against its nature, therefore, me and my department fellows also started online teaching for the first year B.V.Sc. \& A.H. students in the middle of April of this pandemic year at the College of Veterinary Sciences and Animal Husbandry, Aizawl, Mizoram. We usually teach the subject of veterinary anatomy system-wise with subsections such as gross, histological, ultrastructural and developmental anatomy. In the initial stages of this online teaching and learning, the students enjoyed the learning process as they were at their respective places; however, the scenario changed as it was not easy to understand the practical aspects of veterinary anatomy for the students in virtual mode. Receiving and answering the individual phone calls was also not appropriate for us to explain to them about this subject. It was feasible to teach the gross in virtual mode, however not an easy task to perform histology, ultrastructural and developmental anatomy (Fig. 1) in the virtual teaching method. We thought of taking students' opinion regarding virtual education and after getting their personal views, I found that most of the students were not in favour of online platforms and the reasons cited were network issues, as most of our students from North-East India were from either rural or suburban areas. We created a WhatsApp group and Google classroom forum for the students and tried to make teaching feasible by uploading them into the group, which was the only method to explain them veterinary anatomy practically and clear their doubts. We started getting huge positive responses from our students for this innovative teaching; however, something was still missing vis-a-vis the face-to-face teaching methodology.

Although veterinary teachers across the nation are trying their best to educate their students using different available online platforms, however, practical work is missing. Being a veterinary anatomy teacher, initially, it was not possible for us to teach the subject in this hard year of pandemic. On regular days, we used to take theory classes in the morning, followed 


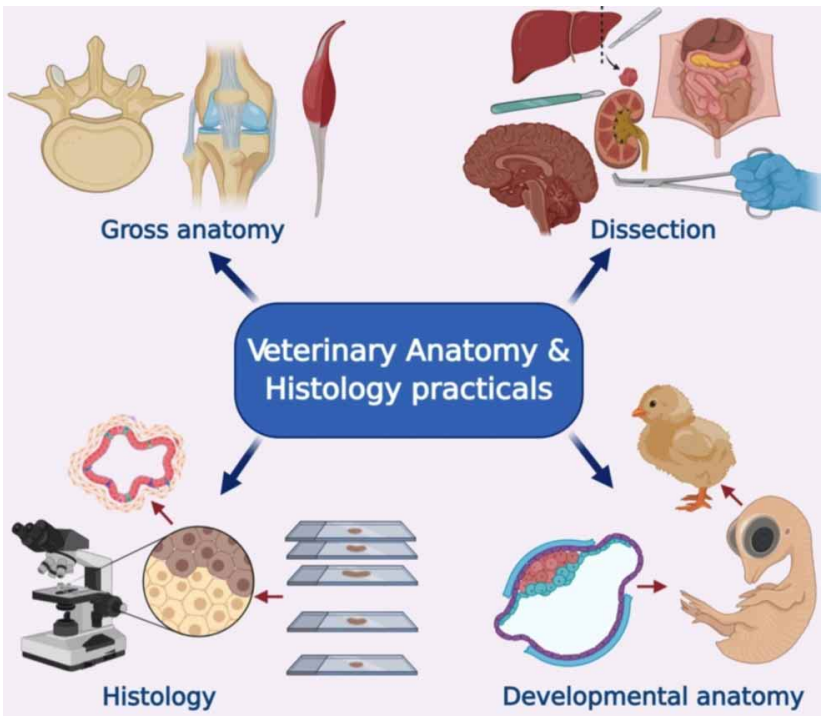

Fig. 1. An illustration of the hands-on practicals in the veterinary anatomy and histology.

by the dissection of a particular region in the afternoon session so that students can see and feel the anatomical structures over the animal body systematically. Dissection method gives students three dimensional image of animal anatomy, corroborates and gives details about the information gained by lectures. However, suddenly, we have entered into a virtual world of teaching and learning after a nationwide lockdown was announced. Despite the advances in technology, cadaveric dissection has been believed to be the ideal and the most effective method of teaching anatomy (Ghosh, 2017).

We have carried out an internal theory assessment by using Google classroom in the form of a quiz; however, some students faced difficulty in giving the examination due to poor internet connectivity.

Recently we have conducted an online viva-voce for the practical examination of the first-year students in the month of November, and I felt that the virtual mode is not a good way to teach the students, especially for the practical subjects. When students lost access to dissection rooms, they lost access not only to cadavers, but also to a range of other optimal learning modalities: prosections, models, pathology specimens, skeletons, and others (Sugand et al., 2010). I want to congratulate all the students who got benefited during this COVID-19 pandemic in terms of relaxed evaluation, but behind the scenes, reality is a compromise on the hands-on practical knowledge.

Now I am writing our story, when it is already eight months in this virtual world of veterinary anatomy, and conclusively I am eagerly waiting to go back to the D-hall 'where death laughs to teach the living' (Patra et al., 2020).
CHOUDHARY, O. P. Consecuencias de la pandemia de COVID19 en la educación en anatomía veterinaria en India. Int. J. Morphol., 39(2):623-624, 2021.

RESUMEN: Mientras el mundo lucha por hacer frente al SARS-CoV-2, el agente etiológico del COVID-19, que ha provocado una pandemia mundial que desafía las fronteras geográficas y pone en riesgo la vida de miles de millones (Priyanka et al., 2020), la pregunta más crítica que deben dilucidar los docentes de la educación, es si la modalidad virtual de enseñanza continuará o volveremos al escenario pre-COVID de enseñanza y aprendizaje. Siendo profesor asistente de anatomía veterinaria, como docente de los estudiantes matriculados en el primer año de Licenciatura en Ciencias Veterinarias y Ganadería (BVSc. \& AH), sentí que era esencial comentar sobre el impacto de la pandemia de COVID-19 en la educación anatómica en India (Franchi, 2020). La situación actual de la educación virtual puede afectar el futuro de los estudiantes de veterinaria actuales, ya que prácticamente no pueden contar con conocimientos sólidos dependiendo de las teorías.

PALABRAS CLAVE: Educación en Anatomía Veterinaria; SARS-CoV-2

\section{REFERENCES}

Franchi, T. The impact of the Covid-19 pandemic on current anatomy education and future careers: a student's perspective. Anat. Sci. Educ., 13(3):309-12, 2020.

Ghosh, S. K. Cadaveric dissection as an educational tool for anatomical sciences in the 21st century. Anat. Sci. Educ., 10(3):286-99, 2017.

Patra, A.; Ravi, K. S. \& Chaudhary, P. COVID 19 reflection/experience on teaching-learning and assessment: story of anatomy teachers in India. Anat. Sci. Int., 2020. DOI: https://www.doi.org/10.1007/s12565-02000576-6

Priyanka; Choudhary, O. P.; Singh, I. \& Patra, G. Aerosol transmission of SARS-CoV-2: The unresolved paradox. Travel Med. Infect. Dis., $37: 101869,2020$

Sugand, K.; Abrahams, P. \& Khurana, A. The anatomy of anatomy: a review for its modernization. Anat. Sci. Educ., 3(2):83-93, 2010.

Worldometer. Covid-19 Coronavirus Pandemic, Geneva, Worldometer Information Technology \& Services, 2020. Available from: https:// www.worldometers.info/coronavirus

Corresponding author:

Dr. Om Prakash Choudhary

Department of Veterinary Anatomy and Histology

College of Veterinary Sciences and Animal Husbandry

Central Agricultural University (I)

Selesih, Aizawl-796 015

Mizoram

INDIA

E-mail:dr.om.choudhary@gmail.com

Received: $26-12-2020$

Accepted: 20-01-2021 